\title{
The Effect of Portfolio and Self Assessment on Writing Ability and Autonomy
}

\author{
Ebrahim Khodadady \\ Ferdowsi University of Mashhad, Iran \\ Hossein Khodabakhshzade \\ English Department, Islamic Azad University, Torbat-e- Heidarieh branch, Torbat-e-Heidarieh, Iran \\ Email: hkhodabakhshzade@gmail.com
}

\begin{abstract}
This study explored the effect of portfolio and self assessment on writing tasks on the one hand and self regulation ability on the other by assigning sixty freshman undergraduate university students majoring in teaching English as a foreign language to a control and experimental group. They had enrolled in the Writing Essay course at Tabaran University in Iran in 2010. While both groups wrote several essays during the course and took a self regulation questionnaire and the same writing task at the beginning and end of the course as pre-and-post tests, only the participants in the experimental group were required to write portfolios regularly and perform self assessment tasks. The multivariate analysis of results showed that the two groups had no significant difference in their writing and self-regulation abilities when the course started. The experimental group, however, did not only score significantly higher than the control group on the writing task $(F=14.390$, df $=1, p<.000$ ) but also gained higher self regulation ability as a result of writing portfolios and self assessment $(F=58.235$, df $=1, p<.000)$. The implications of the study are discussed within a foreign language teaching context.
\end{abstract}

Index Terms—portfolio, self assessment, autonomy, writing ability

\section{INTRODUCTION}

The ability to foster an autonomous learning environment which is enhanced by portfolio and self assessment as true examples of what scholars find satisfactory alternatives in assessment (Brown and Hudson, 1998; Norris, Brown, Hudson, and Yoshioka, 1998), seems to be a demanding job in an exam-oriented culture like Iran. Students' writing ability in second language in this culture is usually assessed by a paper and pencil summative test at the end of the term, which is mostly a product-oriented pedagogy not involving the process as the best indicative of the students' improvement.

What seems to be the main concern in this context is the lack of research demonstrating conclusively that creating the assessment for learning culture not only pushes the frontier of language assessment towards more formative progressive assessment but it helps the learners take advantage of an autonomous atmosphere created by this alternative assessment (Chen, 2008).

One of the trends in the changing world of language assessment has been promoting learners' self-assessment, facilitated by the explicit descriptive criteria in curriculum standards (Little, 2005; Ross, 1998). Another one has been portfolios that are effective for writing courses in different ways such as skill development as well as tracing the students' growth in university classrooms (Kathpalia and Heah, 2008). Portfolio assessment in the field of writing can be defined as "a collection of texts the writer has produced over a defined period of time" (Hamp-lyons, 1991; p.262). ). Assessment for learning is, in fact, the best counterpart for the emerging process approach of writing. Through portfolio and self-assessment learners are allowed to learn while checking the multifaceted process of writing skill.

Genesee and Upshur (1996) state that portfolio assessment imposes a sense of ownership which is enhanced by the fact that portfolio experience is not a brief one-shot presentation of writing. Portfolio assessment, in fact, appears to show the greatest promise in enhancing different dimensions of learning and promoting autonomy (Chen, 2006). As far as one of the important concepts in portfolio pedagogy is the students reflection on their writing papers collected in their portfolio (Fink, 2004; Jones and Shelton, 2006; Zubizarreta, 2004). Kathpalia and Heah, (2008) argue "a writing portfolio without reflection is merely a collection of written work which does not contribute to 'real' learning". Diminishing this gap, we tried to integrate self assessment with portfolio assessment along with comprehensive instruction as well as predetermined criteria to enable learners examine their work by reflecting on what they have done. The rationale behind this integration was to provide students with a valuable opportunity to reflect on their writing activities based upon a standardized thought provoking checklist. Little (2005) calls this process formalizing, through which we can make the portfolio and especially self-assessment as reflective as possible.

This study hopefully tries to turn the attention of the TEFL teachers towards the notion of 'assessment culture' (Lynch and Shaw, 2005) that mentions "students should be active participants in the process of developing assessment 
procedures..." (p. 265). Active involvement of the learners in assessing their performance will enable them gain ownership of their learning (Chen, 2008). The assumption behind this study is that this type of involvement will not only improve students authority both in the realm of assessment and learning but will optimistically change the trend of exam-oriented culture in the present educational context which seems to serve no purpose except measuring the learners' ultimate ability.

\section{Self-assessment, portfolio assessment, and writing ability}

Assessment for learning is the best counterpart for the emerging process of writing. Through portfolio and self assessment learners are allowed to learn while checking the multifaceted process of writing skills. Portfolio assessment in the field of writing can be defined as "a collection of texts the writer has produced over a defined period of time" (Hamp-lyons, 1991, p. 262). Ghoorchaei, Tavakoli and Ansari (2010) investigated the effect of portfolio assessment as a process-oriented assessment mechanism on Iranian EFL students' English writing ability. The findings showed that portfolio assessment empowers students' learning of English writing. Lam and Lee (2009) emphasize the formative role of portfolio assessment. Conducting the research they try to underscore the formative role of the portfolio assessment and how it can effectively align teaching with assessment. Almost all of the students' conceptions about the effect of formative portfolio assessment on their writing ability were positive. The role of formative portfolio assessment was also highlighted by the instructors in in this study.

Buyukduman and Sirin (2010, p. 56) believe that "since education is inherently interdisciplinary, the only valuable way to measure learning is to make the assessment part of the learning process, ensuring it provides students with information on the quality of their learning. The findings of their study indicated that the learning portfolio made the students take the responsibility, do some research and gave them the chance to learn at their own pace.

Portfolios must demonstrate some features to be considered as good examples of alternative assessment. Among these features, students' reflection has been highlighted (Lynch and Shaw, 2005). Self-assessment included in the process of selecting, reading and feedback can foster learners' reflection on their activities compiled in portfolio. Including self-assessment in the process of portfolio assessment will cover the lack of constructive feedback, which is observable in traditional achievement tests. "To encourage deep learning, teachers should give students an opportunity to engage in reflective dialogue and self-assessment". (Kathpalia and Heah, 2008). Fink (2004) states that this type of reflection provided by self-assessment will make students more mindful and more aware of their own learning especially in how and what of their learning. Kohonen (2000) points out that Portfolio assessment opens new ways for promoting the learner autonomy not just by telling them that they are in charge of their learning but by making this visible to them. Making students conscious and reflective about their learning is a difficult task which should be made more feasible by means of a criterion-refrenced plan such a predetermined organized self-assessment.

It has strongly been argued that self-assessment is an integrated part of autonomous learning (Holec, 1981; Tudor, 1996; Thomson, 1996). The role of self-assessment in promoting learner autonomy has been underscored to the extent that Hunt, Gow, and Barnes (1989) argue that without learner self-assessment and evaluation "there cannot be real autonomy" (p. 207). In a recent study, Little (2005) states that self-assessment promote learner autonomy. He emphasizes the important role of self-assessment in reflective learning. He argues that students should submit an evaluative account of their activities included in the portfolio or to rate their portfolio against a checklist as a guide to the portfolio process from the beginning. He also takes account of three reasons for engaging learners in self-assessment. Firstly, it involves students in the process of curriculum evaluation. Secondly, self-assessment in a learner centered pedagogy shapes the processes on which the learner autonomy develop. Thirdly, it provides learners with opportunities to use their knowledge beyond the classroom.

\section{METHODOLOGY}

\section{A. Research Questions}

This study thus aims at investigating the effect of two types of alternative assessments on the TEFL students' writing autonomy improvement as well as their general ability in writing. To do so, answering the following questions seems inevitable.

1. Do self and portfolio types of assessments as part of the ongoing instructional course, improve the students' autonomy in writing?

2. Do self and portfolio types of assessments have any effect on the students' general writing ability?

\section{B. Participants}

The study was conducted on 59 TEFL students attending the writing class at Tabaran university in the 2010-2011 academic year fall semester. The majority of them $(88.3 \%)$ were female and 11.7 percent were male, native speakers of Persian, between 18-34 years old, and highly motivated to pass the writing course. The participants were divided into experimental and control groups. The study lasted for 16 weeks and the participants in both groups received instruction according to the pre-planned procedure.

\section{Instruments}


The instruments used in this study were a writing IELTS task and the Motivated Strategies for Learning Questionnaire (Pritrich et al., 1991). The first one which was used both as a pre and post test enabled us to to determine the level of the students' writing ability as well as their improvement during the course. The second instrument was used to determine the students' autonomy in writing.

We used this self-regulation questionnaire as a mean to examine the students' autonomy as the argues go that these strategies have been used in the literature to describe both autonomous and self-regulated learners (Wenden, 1995; and Lee, 1998). Wenden (1995) has strongly emphasized a strong relationship between autonomy and self-regulation.

Hue (2008) also argues that self regulated strategy development as a possible solution to the problem of fostering learning autonomy (p. 248).

The students in both experimental and control groups participated in the writing task as the pre and post test. They also participated in the questionnaire at the very beginning and end of the term.

\section{Procedure}

Our experience with TEFL students in Iran suggests that learning autonomy can not be improved just by indirect hints given to students but by means of predetermined criterion-oriented planned interactive activities led by the instructor along with vivid rubrics so that students would find themselves capable of controlling their learning. Organized criterion-oriented self assessment integrated with Portfolio assessment helped both teacher and students get at the heart of autonomous learning little by little. This notion is in line with the notion of a number of scholars in 1990s who sought to operationalize the idea that autonomy is a matter of degree (Nunan, 1997). Therefore, what is worthy doing in this context is not an attempt to produce autonomy but a logical trend along with patience to foster and build upon what learners already possess. Accordingly, we decided to divide the treatment into two phases. In the first phase, we provided learners with with enough instruction in how to select, collect and reflect on their activities (Hamp-lyons and Condon, 2000) in their portfolios as well as filling the self-assessment checklists through which they could improve their independent sel-control and autonomy in writing.

In the first phase, the students in the experimental group were given instructions during the first four weeks. They were required to write one task inside the classroom and one outside on different topics. They prepared files to keep record of their tasks in order. Since we found out that self-assessment by means of checklists need intensive instruction, we corrected the students' tasks using the checklists each session and discussed the content of them in the class along with individual conference. After four weeks students felt they could follow the instruction in how to self-evaluate their papers using the checklist. From the fifth session, they showed improvement in self-correction. We found the first four weeks of the term quite efficient for teaching students how to work with the checklist. We could also pilot the checklist during this period.

In the second phase, students showed improvement in self-assessing their tasks using the checklist. The teacher decided to decrease the teacher-student conference sessions and finally stop them except for some of the students who needed more help. For the second half of the term almost all of the students could self evaluate their papers, fill the checklists out, and add them to their portfolio to be randomly checked by the teacher.

After that, we checked the students' portfolios every other week and recorded the feedbacks in the portfolio checklists. In this way, both students and teacher reflected on the whole activities recorded in the portfolio.

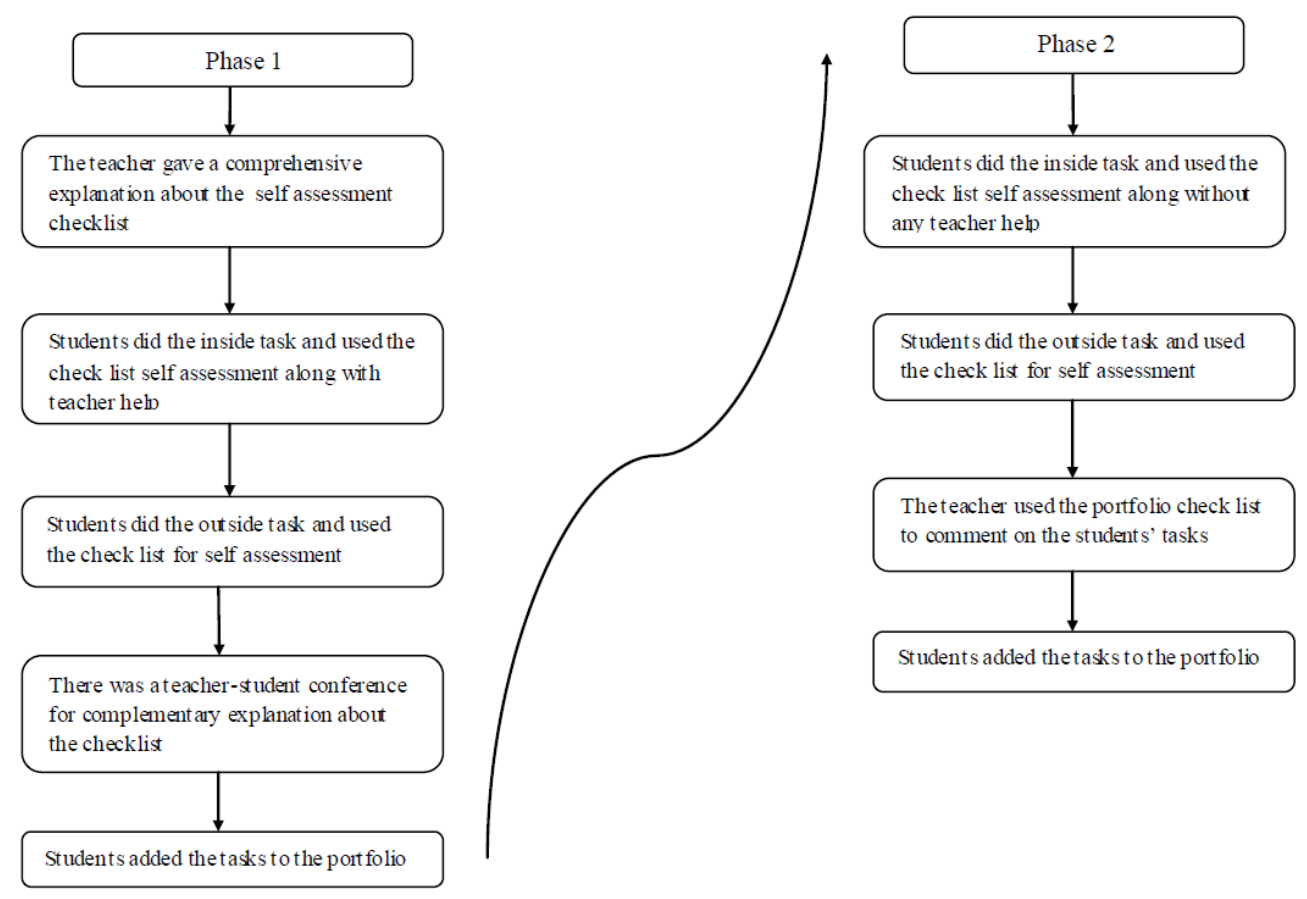




\section{RESULTS}

This study aimed at finding the impact of portfolio and self-assessment on writing and autonomy abilities of the TEFL students. For this purpose the following null hypotheses were formulated to be examined.

1. Self and portfolio types of assessments as part of the ongoing instructional course, do not improve the students' autonomy in writing.

2. Self and portfolio types of assessments do not have any effect on the students' general writing ability.

In order to investigate the above-mentioned hypotheses, various statistical analyses including descriptive and referential statistics were conducted to accomplish the purpose.

Descriptive statistics for the two groups on each of the measures are shown in table 1. In each case, standard deviations, means, number of participants and items are shown.

In order to ensure that students in the two groups began the study with similar writing proficiency, an independent sample t-test was performed.

Results are shown in table 2.

TABLE 1

DESCRIPTIVE STATISTICS OF PRETEST AND FINAL EXAMINATION

\begin{tabular}{|l|l|l|l|l|l|}
\hline Tests & Group & $\mathrm{N}$ & Mean & Std. Deviation & Std. Error Mean \\
\hline Pretest & Control & 28 & 9.107 & 1.6179 & .3058 \\
\cline { 2 - 6 } & experimental & 30 & 9.283 & 1.8648 & .3405 \\
\hline \multirow{2}{*}{ Final examination } & Control & 28 & 13.8036 & 1.67409 & .31637 \\
\cline { 2 - 6 } & experimental & 30 & 15.4667 & 1.65015 & .30127 \\
\hline
\end{tabular}

TABLE 2

INDEPENDENT SAMPLES TEST OF THE PRETEST

\begin{tabular}{|c|c|c|c|c|c|c|c|c|c|}
\hline & \multicolumn{2}{|c|}{$\begin{array}{l}\text { Levene's Test for } \\
\text { Equality of Variances }\end{array}$} & \multicolumn{7}{|c|}{ t-test for Equality of Means } \\
\hline & \multirow[b]{2}{*}{$\mathrm{F}$} & \multirow[b]{2}{*}{ Sig. } & \multirow[b]{2}{*}{$\mathrm{T}$} & \multirow[b]{2}{*}{ Df } & \multirow{2}{*}{$\begin{array}{l}\text { Sig. }(2- \\
\text { tailed) }\end{array}$} & \multirow{2}{*}{$\begin{array}{l}\text { Mean } \\
\text { Difference }\end{array}$} & \multirow{2}{*}{$\begin{array}{l}\text { Std. Error } \\
\text { Difference }\end{array}$} & \multicolumn{2}{|c|}{$\begin{array}{l}95 \% \text { Confidence Interval of } \\
\text { the Difference }\end{array}$} \\
\hline & & & & & & & & Lower & Upper \\
\hline $\begin{array}{l}\text { Equal variances } \\
\text { assumed }\end{array}$ & .652 & .423 & -.383 & 56 & .703 & -.1762 & .4599 & -1.0974 & .7450 \\
\hline $\begin{array}{l}\text { Equal variances not } \\
\text { assumed }\end{array}$ & & & -.385 & 55.716 & .702 & -.1762 & .4576 & -1.0930 & .7406 \\
\hline
\end{tabular}

As shown in table 2, the $\mathrm{p}$ value is not lower than .05. This shows that there is no difference between the experimental and control group with respect to writing ability at the very beginning of the study.

In order to show the initial position of the students with respect to their self-regulation ability in writing, an independent samples t-test was used. The results can be observed in table 4 .

TABLE 3

DESCRIPTIVE STATISTICS OF PRETEST SELF REGULATION QUESTIONNAIRE WITH THE NORMAL SCORES AND AVERAGED SCORES

\begin{tabular}{|ll|l|l|l|l|}
\hline Score & Group & N & Mean & Std. Deviation & Std. Error Mean \\
\hline Normal & Control & 28 & 100.11 & 5.711 & 1.079 \\
& Experimental & 30 & 100.07 & 6.153 & 1.123 \\
\hline Averaged & Control & 28 & 3.2039 & .20270 & .03831 \\
& Experimental & 30 & 3.2656 & .16830 & .03073 \\
\hline
\end{tabular}

TABLE 4

INDEPENDENT SAMPLES TEST

\begin{tabular}{|c|c|c|c|c|c|c|c|c|c|}
\hline & \multicolumn{2}{|c|}{$\begin{array}{l}\text { Levene's Test for } \\
\text { Equality of Variances }\end{array}$} & \multicolumn{7}{|c|}{ t-test for Equality of Means } \\
\hline & \multirow[b]{2}{*}{$\mathrm{F}$} & \multirow[b]{2}{*}{ Sig. } & \multirow[b]{2}{*}{$\mathrm{T}$} & \multirow[b]{2}{*}{ Df } & \multirow{2}{*}{$\begin{array}{l}\text { Sig. (2- } \\
\text { tailed) }\end{array}$} & \multirow{2}{*}{$\begin{array}{l}\text { Mean } \\
\text { Difference }\end{array}$} & \multirow{2}{*}{$\begin{array}{l}\text { Std. Error } \\
\text { Difference }\end{array}$} & \multicolumn{2}{|c|}{$\begin{array}{l}95 \% \text { Confidence Interval } \\
\text { of the Difference }\end{array}$} \\
\hline & & & & & & & & Lower & Upper \\
\hline Pre Equal variances assumed & .016 & .898 & .026 & 56 & .979 & .040 & 1.562 & -3.088 & 3.169 \\
\hline 31 Equal variances not assumed & & & .026 & 55.999 & .979 & .040 & 1.558 & -3.080 & 3.161 \\
\hline Pre Equal variances assumed & .774 & .383 & -1.264 & 56 & .211 & -.06167 & .04879 & -.15942 & .03607 \\
\hline Equal variances not assumed & & & -1.256 & 52.635 & .215 & -.06167 & .04911 & -.16019 & .03684 \\
\hline
\end{tabular}


On examining table 4, it can be found that there is no significant difference between the experimental and control groups with respect to their initial position in autonomy.

In order to investigate the first null hypothesis, i.e., Self and portfolio types of assessments as part of the ongoing instructional course, do not improve the students' autonomy in writing, an independent sample t-test was used. The result can be observed in table 6 .

TABLE 5

DESCRIPTIVE STATISTICS OF POSTTEST SELF REGULATION QUESTIONNAIRE WITH THE NORMAL SCORES AND AVERAGED SCORES

\begin{tabular}{|ll|l|l|l|l|}
\hline \multicolumn{2}{|c|}{ Group } & $\mathrm{N}$ & Mean & Std. Deviation & Std. Error Mean \\
\hline Normal & Control & 28 & 105.64 & 4.794 & .906 \\
& Experimental & 30 & 94.87 & 5.818 & 1.062 \\
\hline Averaged & Control & 28 & 3.4078 & .15463 & .02922 \\
& Experimental & 30 & 3.0602 & .18766 & .03426 \\
\hline
\end{tabular}

TABLE 6

INDEPENDENT SAMPLES TEST OF THE POST TEST SELF REGULATION WITH NORMAL AND AVERAGED SCORES

\begin{tabular}{|c|c|c|c|c|c|}
\hline & \multicolumn{2}{|c|}{ Levene's Test for Equality of Variances } & \multicolumn{3}{|c|}{ t-test for Equality of Mean } \\
\hline & $\mathrm{F}$ & Sig. & $\mathrm{T}$ & Df & Sig. (2-tailed) \\
\hline $\begin{array}{l}\text { Normal Equal variances } \\
\text { assumed } \\
\text { Equal variances not assumed }\end{array}$ & 1.217 & .275 & $\begin{array}{l}7.668 \\
7.719\end{array}$ & $\begin{array}{l}56 \\
55.177\end{array}$ & $\begin{array}{l}.000 \\
.000\end{array}$ \\
\hline $\begin{array}{l}\text { Average Equal variances } \\
\text { assumed } \\
\text { Equal variances not assumed }\end{array}$ & 1.217 & .275 & $\begin{array}{l}7.668 \\
7.719\end{array}$ & $\begin{array}{l}56 \\
55.177\end{array}$ & $\begin{array}{l}.000 \\
.000\end{array}$ \\
\hline
\end{tabular}

Table 6 shows that the $t$ value for the two variables if 7.668. The criterion for statistical significance at alpha=.05 and degrees of freedom of 56 is 2.000 (two-tailed test). Accordingly, the first null hypothesis which stated that self and portfolio types of assessments do not improve the students' autonomy in writing, is rejected.

In order to investigate the second null hypothesis i.e., Self and portfolio types of assessments do not have any effect on the students' general writing ability, an independent samples t-test was used.

TABLE 7

INDEPENDENT SAMPLES TEST OF THE FINAL EXAMINATION

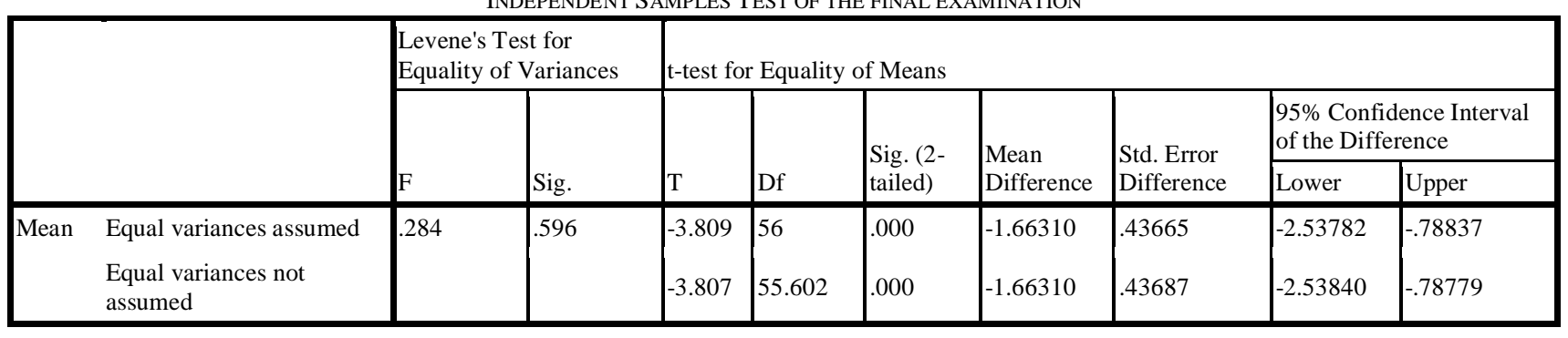

As can be found in table 7 There are statistically significant differences between the groups in the writing ability (the $\mathrm{p}$ value is less than .05). Therefore the second null hypothesis which stated that Self and portfolio types of assessments do not have any effect on the students' general writing ability, is rejected.

To investigate the effect of Portfolio and self-assessment on students' writing ability as well as autonomy in writing, an ANCOVA on post self-regulation scores by group (experimental vs. control), using pre self-regulation scores as a covariate was conducted.

TABLE 8

TESTS OF BETWEEN-SUBJECTS EFFECTS (DEPENDENT VARIABLES: POST TEST SELF-REGULATION AND POST TEST ESSAY WRITING TASK, FIXED FACTOR: GROUP; COVARIATE PRETEST SELF-RGULATION)

\begin{tabular}{|ll|l|l|l|l|l|}
\hline Source & $\begin{array}{l}\text { Dependent } \\
\text { Variable }\end{array}$ & $\begin{array}{l}\text { Type III Sum of } \\
\text { Squares }\end{array}$ & df & Mean Square & F & Sig. \\
\hline Group & Post SR & 1682.816 & 1 & 1682.816 & 58.235 & .000 \\
& Post test & 39.999 & 1 & 39.999 & 14.390 & .000 \\
\hline Error & Post SR & 1589.332 & 55 & 28.897 & & \\
& Post test & 152.886 & 55 & 2.780 & & \\
\hline Total & Post SR & 584084.000 & 58 & & & \\
& Post test & 12666.250 & 58 & & \\
\hline \multicolumn{7}{|l|}{ a. R Squared = .516 (Adjusted R Squared $=.498)$} \\
\end{tabular}


Table 8 shows that there is a significant difference in posttest scores between groups.

\section{DisCUSSION AND CONCLUSION}

The findings from this study appear to demonstrate the strength of alternatives in assessment i.e., prtofolio assessment and self-assessment, to enhance the students' writing ability as well as their autonomy in writing. We chose two groups in a foreign language learning context, one experimental and the other control. In the first phase of the study it seemed quite necessary to familiarize the participants in the experimental group with the procedure of the portfolio and self-assessments. The instruction targeted the self-assessment checklist and gradual autonomous writing activities respectively. The participants in the experimental group soon were acquainted with the procedure and its pleasant independent activities.

The regular implementation of the self-assessment checklist in class as well as outside the class had great effects on students' sense of independency in their writing activities. As the few first sessions elapsed, the students in the experimental group who were once unwillingly using the checklists to monitor their improvement, started implementing the checklists enthusiastically.

To observe this dynamic autonomous trend statistically we administered a self-regulation questionnaire at the very beginning of the course. The first quantitative analysis which was an independent sample t-test showed no difference between the two groups writing ability and autonomy. After a few sessions of instruction on the self-assessment checklists and regular inside class and outside class writing activities, students were left on their own to follow their path toward independent self-assessment. The second independent sample t-test on self-regulation questionnaire showed that the experimental group outperformed the control group with respect to writing autonomy. It suggests that the type of assessment has strong influence on the students writing autonomy. Self-assessment and portfolio assessment are among those alternative types of assessment that lead to autonomous learners. This result echoes the earlier findings in the literature (Butler and Lee, 2010). This success partly can be attributed to the teachers pedagogical intervention as well as the students self-awareness of the journey they took during the course. The students in the experimental group also increased this awareness by reflecting on their self-evaluated writing activities going through the portfolio they had prepared during the term.

The findings in table 7 contribute to the fact that Portfolio and self-assessment not only make learners autonomous in writing but also improve their writing ability. The same significant difference is observable in table 8 . Through an ANCOVA analysis which considers the pretest as the covariate, the significant difference between groups both in self regulation questionnaire as an indication of autonomy and writing ability is quite obvious.

Little (2003) states that the success of the learner autonomy depends on a series of elements such as insight into the nature of independent learning, the right attitude towards this process, a reflective stance vis a vis one's own practice, both self-management and an openness to collaboration, interaction and exchange with one's peers. What is in line with this summary is the assessment for autonomy as opposed to assessment of autonomy (O'Leary, 2007). In other words, portfolio and self-assesment in the present study have focused on the former function to foster learners' autonomy through assessment. O'Leary (2007) also argues that “assessment for, or as, learning which focuses on the process as well as the outcome of the learning, can therefore enhance the student learning experience and foster the development of autonomy" (p.3).

Butler and Lee (2010) speculate that self-assessment helps students reflect on what they have achieved and it would possibly help in teaching and learning environment where effort is a highly valued part of educational success.

Dafei (2007) in his study concluded that the more autonomous a learner becomes the more likely he/she achieves high language proficiency. This outcome is congruent with the findings of the present study according to which the idea of writing ability improvement is in line with writing autonomy development. In fact, as the students' writing autonomy develops, their writing ability improves too.

\section{REFERENCES}

[1] Brown, J. D., \& Hudson, T.D. (1998). The alternatives in language assessment. TESOL Quarterly, 32, 653-675.

[2] Butler, Y. G. \& Lee, J. (2010). The effect of self-assessment among young learners of English. Language Testing, 27 (1), 5-31.

[3] Buyukduman, L. \& Sirin, S. (2010). Learning portfolio (LP) to enhance constructivism and student autonomy. Procedia Social and Behavioral Science, 3, 55-61.

[4] Chen, Y. M. (2006). EFL instruction and assessment with portfolios: A case study in Taiwan. Asian EFL Journal, 8 (1), $69-96$.

[5] Chen, Y. M. (2008). Learning to self-assess oral performance in English: A longitudinal case study. Language Teaching Research, 12 (2), 235-262.

[6] Dafei, D. (2007). An exploration of the relationship between learner autonomy and English proficiency. Asian EFL Journal, 9(1), 1-23.

[7] Fink, L.D. (2004). Learning Portfolios: A Powerful Tool for Enhancing Course Design, in J. Zubizarreta, The Learning Portfolio: Reflective Practice for Improving Student Learning (Association of Supervision and Curriculum Development; Alexandra, VA), 92-99.

[8] Genesee, F. \& Upshur, J. A. (1996). Classroom-based evaluation in second language education. New York: Cambridge University Press. 
[9] Ghoorchaei, B. Tavakoli, M. \& Nejad Ansari, D. (2010). The impact of portfolio assessment on Iranian EFL students' essay writing: A process-oriented approach. GEMA Online Journal of Language Studies, 10 (3), 35-51.

[10] Hamp-Lyons, L. \& Condon, W. (2000). Assessing the portfolio: Principles for practice, theory and research .Cresskill, NJ: Hampton Press, Inc.

[11] Holec, H. (1981). Autonomy and foreign language learning.(First published 1979, Strasbourg: Council of Europe). Oxford: Pergamon.

[12] Hue, N. M. (2008). Self-regulated strategy development as a means to foster learner autonomy in a writing course. $V N U$ Journal of Science, Foreign Languages, 24 (2), 246-253.

[13] Hunt, J., Gow, L. \& Barnes, P. (1989). Learner self-evaluation and assessment - a tool for autonomy in the language learning classroom, in V. Bickley (Ed.). Language Teaching and Learning Styles Within and Across Cultures. Hong Kong: Institute of Language in Education, Education Department, 207-217.

[14] Jones, M., \& M. Shelton, (2006). Developing your Portfolio: Enhancing your Learning and Showing your Stuff. New York: Routledge.

[15] Kathpalia, S. \& Heah, C. (2008). Reflective writing: Insights into what lies beneath. Relc Journal, 39 (3), 300-317.

[16] Lam, R. \& Lee, I. (2010). Balancing the dual functions of portfolio assessment. ELT Journal Volume 64 (1), 54-64.

[17] Lee, I. (1998). Supporting greater autonomy in language learning. ELT Journal, 54 (4), 282-288.

[18] Little, D. (2003). Learner autonomy and second/foreign language learning. Subject Center for Languages, Linguistics and Area Studies, Guide to good practice. Retrieved September 8, 2007, from http://www.llas.ac.uk/resources/gpg/1409.

[19] Little, D. (2005). The common European framework and the European language portfolio: involving learners and their judgments in the assessment process. Language Testing, 22 (3), 321-336.

[20] Lynch, B. \& Shaw, P. (2005). Portfolio, power and ethics. Tesol Quarterly, 39(2), 263-297.

[21] Norris, J, M., Brown, J. D., Hudson, T., \& Yoshioka, J. (1998). Designing second language performance assessments. Honolulu, HI: University of Hawai'I Press.

[22] Nunan, D. (1997). Designing and adapting materials to encourage learner autonomy. In P. Benson \& P. Voller (Eds), Autonomy and Independence in Language Learning, 192-203. London: Longman.

[23] O'Leary, Ch. (2007). Should learner autonomy be assessed? Proceedings of the Independent Learning Association, Japan.

[24] Ross, S. (1998). Self-assessment in second language testing: A meta analysis and analysis of experimental factors. Language Testing, 15 (1), 1-19.

[25] Wenden, A. L. (1995). Learner training in context: A knowledge-based approach. System 23 (2), 183-194.

[26] Zubizarreta, J. (2004). The Learning Portfolio: Reflective Practice for Improving Student Learning. Bolton, MA: Anker.

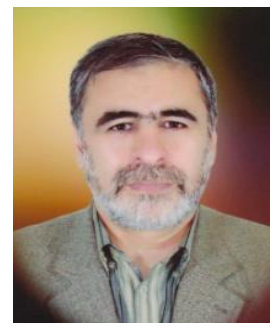

Ebrahim Khodadady was born in Iran in 1958. He obtained his PhD in Applied Linguistics from the University of Western Australia in 1998. He holds TESL Ontario and Canadian Language Benchmarks Placement Test (CLPBPT) certificates and has taught English as a first, second and foreign language to high school and university students in Australia, Canada and Iran.

$\mathrm{He}$ is currently an academic member of English Language and Literature Department at Ferdowsi University of Mashhad, Iran. He was invited as a VIP by Brock University in Canada in 2004 and served as the Associate Director of Assessment Center at George Brown College in Toronto for almost a year. His published books are Multiple-Choice Items in Testing: Practice and Theory (Tehran, Rahnama, 1999), Reading Media Texts: Iran-America Relations (Sanandaj, Kurdistan University, 1999) and English Language Proficiency Course: First Steps (Sanandaj, Kurdistan University, 2001). His main research interests are Testing, Language Learning and Teaching.

Dr. Khodadady is currently a member of TESL Ontario and European Society for Translation Studies. He is on the editorial board of Ferdowsi Review: An Iranian Journal of TESL, Literature and Translation Studies and has reviewed some research papers for Iranian Journal of Applied Linguistics and TESL Canada Journal as a guest reviewer.

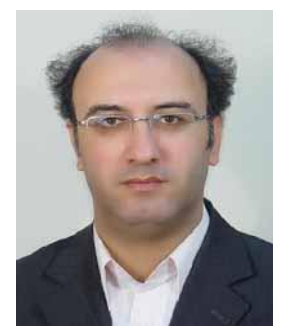

Hossein Khodabakhshzade was born in Torbat-e-Heidarieh in 1353 and revieved hie BA in TEFL from Islamic Azad University of Torbat-e-Heidarieh in 1376. He persued his education at Iran University of Science and Technology and obtained MA in TEFL. He is currently a PhD candidate in TEFL at Ferdowsi University of Mashad, Iran.

Serving as a faculty member of Islamic Azad University of Torbat-e-Heidarieh for over a decade, he has taught various courses in TEFL. He has been a Lecturer in Payam noor University of Mashad, Islamic Azad University of Mashad, and Tabaran University. He has been the Head of English department at Islamic Azad University for 3 years. He has also Supervised the Ayande sazan English Institute for more than 10 years and currently is the Supervisor of Hafez and Jahan Elm institutes. He has also had some other executive jobs at Islamic Azad University of Torbat-e-Heidarieh. He has published several articles and has presented articles in national and international conferences. His area of interests are mostly Language assessment, Methodology in language teaching and teacher training. 